Research.

\title{
IMPLEMENTATION OF ENVIRONMNETAL MANAGEMENT ACCOUNTING (EMA) TO ACHIEVE COMPETITIVE ADVANTAGE
}

\author{
Syarief Gerald Prasetya* \\ Department of Accounting. Universitas Binaniaga Indonesia
}

corresponding author ${ }^{1}$

Received: September 6, 2021 Accepted: December 26,2021 Published: December 30, 2021

To cite this article: Prasetya, SG. (2021). Implementation Of Environmnetal Management Accounting (Ema) To Achieve Competitive Advantage The Accounting Journal of BINANIAGA. 6 (2), 93-104 doi: 10.33062/ajb.v6i2.458

\begin{abstract}
Environmental Management Accounting (EMA) is implemented to improve company's environmental performance. In the traditional accounting system, environmental management is always associated with costs that can reduce company profits. Unlike the case with EMA which makes environmental management an investment that is expected to increase profits while developing the company continuously to achieve competitive advantage. This study aims to analyze environmental management accounting in which can create a competitive advantage. The approach model used in this study is a literature approach. The results of the study explain that every company that carries out activities using environmentally friendly concepts through the implementation of Environmental Management Accounting (EMA) will have a higher value than other companies, because the implementation of Environmental Management Accounting (EMA) automatically companies have made good innovations on their products, production process and waste treatment. The conclusion of competitive advantage through the application of EMA can be viewed from the management strategy carried out by the company which includes a low cost strategy, differentiation strategy, focus strategy and innovation strategy
\end{abstract}

Keywords: EMA, competitive advantage, environmental

\section{INTRODUCTION}

The rising of development activities in Indonesia leads to increase some environmental problems. This circumstance is marked by the development of the industrial sector, which have a direct impact on environment. Starting from efforts to obtain raw materials to the rest of the production process (Jasch and Stasiskiene, 2005).Most of the raw materials for the industrial sector come from nature. To obtain these raw materials, companies often ignore the existence of natural resources. They exploit natural resources without any further conservation efforts. This condition causes damage to the natural environment along with the loss of these natural resources. The companies' production activities also produce waste that is not good for the surrounding environment, both for nature and for humans (Chenhall, 2003). Most companies do not manage their waste properly as well as disposes of its production waste arbitrarily, so that it endangers the surrounding environment.

The production activities carried out by this industry clearly contradict with the concept of sustainable development. This concept is explained by Burrit and Lehman (1995) who said that the principle of development is carried out to meet the needs of the present generation without compromising the needs of future generations. It means that development through the development of activities in the industrial sector should not 
deplete and even destroy natural resources that should be used by the next generation. Therefore, referring to the concept of sustainable development, development goals are comprehensive, namely not only by meeting economic interests, but also by meeting social interests and the surrounding natural environment.

Two parties, social environment (community) and natural environment (ecology), are often disadvantaged from development activities (industry). Pollution and environmental destruction will automatically have an impact on society. For example, the textile industry activities that dispose of waste in the river will impact not only the river environment, but also people around the river. In order to balance the economic, social and environmental interests in industrial activities, the implementation of management accounting based on the environment should be implemented by the company. This implementation will be related to the environmental performance predicate achieved by the company.

Environmental performance can be defined as the result of environmental management. Then, Environmental Management Accounting (EMA) is implemented to improve the company's environmental performance. Within environmental management, information is always needed about the environment in which the company operates. In the traditional accounting system, environmental management is always associated with costs that can reduce company profits. Unlike the case with EMA which makes environmental management as an investment that is expected to increase profits while developing the company continuously.

Environmental management is the center of attention in environmental management accounting, not only by providing monetary data or information but also by providing physical information about environmental management activities (Bartolomeo. et all, 2000). Monetary information describes information about the costs incurred by the company related to inputs and outputs used to minimize environmental impacts. Meanwhile, physical information relates to information about the inputs (raw materials) used for the production process and the outputs produced from production activities in form of products and waste (IFAC, 2005). Physical information (especially waste) is needed to control and minimize environmental impacts, while cost information is needed to control costs as efficiently as possible.

This monetary and physical information are needed by company managers for making decision to manage the company (Chang, 2007). With more comprehensive data on environmental aspects, hopefully it will provide data on the use of energy sources so that it can be more efficient or bring alternative ways for compan to process their waste better (recycling). In reality, not all companies have implemented environmental management accounting. Hence, companies that have been able to utilize data or information about environmental aspects of the implementation of environmental management accounting will have higher value in terms of developing an internal control system than other companies. This is happened due to better decision making than those who do not or have not implemented environmental management accounting. Thus, companies that have implemented environmental management accounting tend to be more efficient and innovative so that they have a competitive advantage.

Competitive advantage is an advantage possessed by a company to win the competition. Competitive advantage according to David (in Ratno and Rosdiayana, 2020) is whatever a company does better than its competitors. A company must have a competitive advantage in order to dominate the market from its competitors. To gain a competitive advantage, a company must use a series of strategies by taking into account the company's internal and external factors. Implementation of environmental management accounting is one strategy that can create competitive advantage. Craven (1996) suggested that there are three sources of a company's competitive advantage, namely superior skills. Companies that have implemented environmental management accounting can be said to be companies that have a competitive advantage. This is 
aligned with the opinion stated above that by implementing environmental management accounting means that the company has carried out activities that are better than other companies. In the sense, company has a better control in system than its competitors. Thus the problem in this research is how environmental management accounting can create a competitive advantage?

\section{LITERATURE REVIEW}

The implementation of Environmental Management Accounting (EMA) is currently used as a tool for management to improve profitability and company performance in order to ensure the long-term sustainability of the company's business activities. During implementation, environmental management accounting allocates environmental costs to products or production processes that can cause emissions or waste. Company managers must be able to innovate for determining alternatives to prevent or minimize pollution at a lower cost in order to increase company profits.

The description of the benefits for implementing environmental management accounting is described as follows:

a. The implementation of Environmental Management Accounting (EMA) can be viewed from the point of view of compliance with the laws and regulations set by the government. With the implementation of environmental management accounting, the company has carried out activities in accordance with the regulations stipulated in the Law of the Republic of Indonesia number 40 of 2007 article 1 and in the Regulation of the State Minister of the Environment Number 13 of 2010 concerning the Statement of Commitment to Environmental Management and Monitoring. The company's compliance with the applicable laws and regulations will ensure the continuity of the company's business. On the other hand, if they do not implement environmental management accounting, it means violating the laws and regulations that allow for sanctions for the company.

In general, this regulation must be implemented by all business people, whether large, medium, small or micro businesses. However, in reality, not all of these business actors implement environmental management accounting, especially small businesses or industries. Lack of understanding of environmental responsibility causes small business actors do not apply the regulations set by the government. In addition, when viewed from the side of financial records, most industries are less able to make or prepare financial reports properly, so that environmental aspects can be recorded. Thus, this requires guidance both by the government and academia for small industries to be able to take into account environmental aspects.

Research conducted by Gibassier and Alcouffe (2018) explained that his research did not find any role for small and medium enterprises (SMEs) in sustainable development to maintain the existence of the environment. Therefore, it is necessary to involve academics to be involved in SME activities so that they can have better understanding about the importance of implementing Environmental Management Accounting (EMA) in order to realize the success of sustainable development.

This study explains that in order to ensure the success of sustainable development involving all businesses, whether large, medium, small and micro, awareness and understanding of all business actors is required on the importance of environmental and social responsibility in addition to gain profit (profit). To realize this awareness, it is necessary to involve all components, especially academics to provide knowledge and training on environmental aspects to Small and Medium Enterprises (SMEs). If all business actors, especially SMEs, have understood their responsibility to the environment, hopefully sustainable development can be realized. 
b. Implementation of Environmental Management Accounting (EMA) can be used as a form of achieving eco-efficiency. Eco-efficiency is an effort to increase company efficiency by reducing waste output through production processes or environmentally clean technologies (Jasch, C., \& Stasiskiene, Z, 2005). With the implementation of environmental management accounting, it is expected that production activities, starting from the acquisition of raw materials, the process to the resulting product, are expected to adhere to environmentally friendly principles. With the right planning pattern on the use of natural resources (energy), the company's financial efficiency will be realized. In addition, product processes that use the right technology will also streamline the company's finances.

Implementation of management accounting (EMA) has a major influence on the company's finances. The better the implementation of Environmental Management Accounting (EMA), the more efficient the company's finances are. Research conducted by Hatef and Dadashian (2016) found that financial managers' knowledge of environmental aspects has a major influence on financial decisions made by organizations. This can be happened because managers have access to more accurate and comprehensive financial information, therefore with the implementation of Environmental Management Accounting (EMA), hopefully companies can identify environmental aspects, reduce consumption of raw materials and energy (e.g., to reduce costs), manage financial more accurately and reduce waste generated from the production process.

The concept of eco-efficiency according to Hansen and Mowen (2007) is an effort by companies to maintain the production of goods and services so that they can be more useful and minimize environmental impacts that may arise as a result of these production activities or activities. Then the factors that encourage eco-efficiency are as follows:

1) Consumer or customer

One of the impacts of advanced technology and communication development is the transfer of information from source to recipient become faster and easier. This condition leads people to be very easy to get information about environmental damage. Moreover, the information obtained can cause a change in the mindset of products consumed or used by public. The change in people's mindset is that they are more likely to like environmentally friendly products that do not damage or impact the surrounding environment.

\section{2) Company employees/employees}

Currently, there is a tendency for employees to prefer to work in companies that care towards the environment than companies that do not care. A safe, clean and comfortable environment will motivate employees to work better and more productive. Thus, the company's concern for the environment will indirectly improve the company's performance through the work motivation shown by employees.

3) Financial advantage

The implementation of environmentally friendly business activities will provide external benefits to the company. This can be happened because of the risk of environmental damage due to small business activities. Thus, the external benefit received by the company is that there is no expenditure to replace if the environment is damaged.

\section{4) Company image}

The environmental performance achieved by the company will affect the performance of the company's image. Companies which care about the environment tend to have a higher image than companies that are less concerned with the environment. This condition leads the company's position are stronger in tight business competition. 
5) New innovations and opportunities

The application of Environmental Management Accounting (EMA) tends to encourage companies to be more creative to innovate and look for new opportunities that are more environmentally friendly. New innovations and opportunities are related to the activity of producing/developing environmentally friendly products, recycling activities and waste processing activities that have selling value in order to provide additional income for the company.

6) Competitive advantage

Eco-efficiency can also increase the company's competitive advantage compared to other competitors. This can happen because with the implementation of Environmental Management Accounting (EMA) companies can innovate through product creation, recycling and waste treatment. In addition, the company can reduce costs that may arise due to damage to the surrounding environment.

c. Implementation of management accounting (EMA) can be used as an effort to achieve the company's strategic position. As previously explained, the strategic position in question is the company's competitiveness in the long term or more often referred to as the company's competitive advantage. The implementation of Environmental Management Accounting (EMA) causes the company to have advantages compared to its competitors. This condition makes the company's position better in the business competition. With the implementation of Environmental Management Accounting (EMA) the company will have benefit among others (Adediran and Alade, 2013):

1) Improving the image of the company and its products will have an impact on the increasing sales turnover obtained.

2) Increasing the environmental risk rating of the company's activities, so that the image of the company where investors are getting better. This condition makes it easier for companies to get additional capital.

3) Minimizing financial losses that may arise due to environmental damage.

4) Improving the company's profile as a result of increasing corporate responsibility to the environment.

5) Causing companies to be more innovative because of new discoveries through recycling activities and in making environmentally friendly products.

Research conducted by Huseno (2018) found that the implementation of Environmental Management Accounting (EMA) did not cause losses in oil industry companies in Riau. The implementation of Environmental Management Accounting (EMA) actually makes the company have a competitive advantage, which can maintain the company's image because it can manage the natural environment while having good social relations with the surrounding community. Then, research conducted by Jasch and Statiskiene (2005) concluded that Environmental Management Accounting (EMA) is increasingly important for product and production process design, cost allocation and control, budgeting, purchasing, product pricing and performance evaluation. Companies that implement Environmental Management Accounting (EMA) will use it as part of their management system integration,

The results of this study explain that the implementation of Environmental Management Accounting (EMA) has positive impacts on company performance, environmental performance, corporate image and social relations with the community, in the sense that the better the implementation of Environmental Management Accounting (EMA), the higher the company's performance, environmental performance, image of the company in the community as well as increasing good relations with the community (social). 


\section{RESEARCH METHOD}

This study is a library research, which is a series of research activities related to library data collection methods. Library research as a data collection technique is carried out indirectly through reading, recording and processing reports obtained from the research site. This research activity was carried out in August 2021. The approach model used in this study is a literature approach. This is defined as a method that includes all analyzes based on theories, also this study is more of an in-depth discussion of studies sourced from research journals.

\section{RESULTS AND DISCUSSIONS}

Competitive advantage is the success of the company's strategy. Therefore, competitive advantage is generally associated with the strategic management of a company. Competitive advantage makes the company has more value compared to other companies and their competitors. Companies must be able to achieve competitive advantage, because competitive advantage does not only provide benefits for the company, but also provide benefits for consumers and investors.

\section{Benefits of competitive advantage for the company}

Every company always strives to get as much profit as possible. Optimal profit can be obtained by the company if they can overcome increasingly fierce business competition. Companies that are able to compete are those that have more value than competing companies. Competitive advantage can be viewed from product quality, service quality, human resource quality, company financial performance and so on. All of this will make the company's position stronger in the business it runs, therefore in addition to gaining profits, the company will be able to survive the business environment it is running.

\section{Benefits of competitive advantage for consumers}

Competitive advantage is not only needed by the company, but also needed by consumers as users of the company's products. This is possible because every consumer wants a quality product or service that they get from consuming or using the company's products or services. If the quality of the product or service they get is aligned with their wishes or expectations, then consumers will get satisfaction.

The quality of their products and services can be obtained from companies that have advantages compared to other similar companies. Therefore, the company's competitive advantage will ensure the satisfaction of consumers who use the products or services offered by the company. Higher competitive advantage will increase consumer satisfaction and the more satisfied consumers cause sales and profits obtained by the company to increase.

\section{Benefits of competitive advantage for investors}

Not only companies and consumers, investors also need a competitive advantage. Investors as parties who invest their capital in a company have an interest in getting a profit from their investment. Profits can be obtained by managing the company properly so that the company's conditions are profitable. Good company management causes the company to have a competitive advantage over its competitors. Thus, it can be said that the interests of investors to earn profits from invested capital will determine the competitive advantage of the company. 
Before investing in a company, investors will first assess the company's performance. Investors tend to invest their capital in companies that have good performance. Good company performance shows the company has a competitive advantage. If this is realized, then the company is considered worthy by investors to get their funds.

As previously explained, competitive advantage is related to management strategy. The implementation of Environmental Management Accounting (EMA) can be regarded as one of the management strategies. Management strategies used to build competitive advantage related to the implementation of management accounting include:

\section{Low cost strategy (cost leadership)}

The advantages obtained from this low-cost strategy can generally be seen in offering a lower (lower) price compared to the price of products or services offered by competing companies. The low cost strategy can be realized, one of which is done by streamlining the production process so that the production costs incurred can be reduced. With the success of the company in reducing production costs, the company will get greater profits compared to other companies even though the price of the products sold is the same. One of the ways to achieve this low-cost strategy is by implementing Environmental Management Accounting (EMA). This can be realized because with the application of environmental costs the company can minimize the environmental problems it faces. Implementation of Environmental Management Accounting (EMA) results in assessments (monetarily) of environmental costs and impacts, so that companies can improve efficiency from a cost point of view (low cost). Research conducted by Gunawan (2012) explained that companies that apply environmental costs (EMA) would make changes in their production processes and business decisions. However, the cost of implementing environmental management will be covered by the operational cost savings that will be achieved each year.

Based on this research, it can be explained that the implementation of Environmental Management Accounting (EMA) has a negative relationship with operating costs. It means better implementation of Environmental Management Accounting (EMA) tend to decrease operating costs. Therefore, it can be said that the company is more efficient (Prasetya, 2020). The more efficient the company in terms of the production costs incurred, the more superior the company (i.e., has more advantage) compared to other competing companies.

\section{Differentiation Strategy}

The competitive advantage obtained from the differentiation strategy as the service products offered by the company are unique or special compared to the products or services offered by competitors. The uniqueness of this company's product or service will provide something special for consumers, so that it will provide its own value and experience for consumers. One of the product differentiation strategies can be done by implementing Environmental Management Accounting (EMA). This can happen because with the implementation of Environmental Management Accounting (EMA) the company will continue to inovate products and services that are environmentally friendly. With innovations that are carried out continuously, the products or services offered have special features or uniqueness compared to other companies that do not innovate, especially producing environmentally friendly products. Research conducted by Hendaris (2010) found that environmental accounting is related to reporting information on the allocation of company environmental costs and for companies that have implemented environmental accounting will encourage competitive advantage. This can happen because of the application of environmental accounting, 
This study explains that the implementation of Environmental Management Accounting (EMA) has a positive relationship with product differentiation. This positive relationship explains that if the implementation of Environmental Management Accounting (EMA) is getting better, the company tends to have better product differentiation, so that better differentiation causes the company to have a unique or higher advantage compared to other companies.

\section{Focus strategy}

The focus strategy is the strategy needed to achieve or realize a cost leadership strategy and a differentiation strategy. To realize this, what needs to be considered is that the market has potential and sustainable conditions. The potential market can be interpreted that the products or services offered by the company are indeed needed by consumers, so that the products or services produced by the company will be purchased by consumers. As the consequence, the market is sustainable because consumer needs will always be there. Therefore, the company as a provider of products or services needed by consumers must be able to produce products continuously so that consumer needs will continue to be fulfilled. Competitive advantage can be seen from the ability of a company to guarantee the availability of its raw materials for a long period of time. One of the company's production continuity will depend on the availability of raw materials needed to produce a product. Scarcity of raw materials causes companies to be unable to produce products. To ensure the continuity of raw materials, management is needed so that the raw materials continue to exist for a long period of time. One of the main objectives of implementing Environmental Management Accounting (EMA) is to maintain the existence of natural resources/energy (i.e., the raw material for production). Calculation of environmental aspects in the recording of financial statements is expected to preserve the raw materials needed in the production process. Research conducted by Carolina, Martusa and Meythi (2011) concluded that environmental accounting is a means to report an institution (country/city/company/organization) that is associated with the environment. The purpose of implementing environmental accounting is to provide information about the company's operational performance based on environmental protection.

The study explains that the implementation of Environmental Management Accounting (EMA) causes companies to have good performance on environmental protection activities. An increasingly protected environment will ensure the availability of raw materials needed by the company for production activities. Thus the implementation of Environmental Management Accounting (EMA) has a positive relationship with the availability of raw materials which shows better implementation of EMA will cause the availability of raw materials is guaranteed. Hence, companies will have advantages compared to others that do not have guarantees for the existence of their raw materials.

\section{Innovation strategy}

The innovation strategy is carried out by creating or producing products that are completely new and have not available yet on the market. Product innovation can also be done by developing existing products so that they have better quality than before. Innovation activities can be realized if the company has quality resources and complete information on matters relating to a product, such as the availability of raw materials, product processing techniques, consumer tastes, trends and so on. With complete information and supported by adequate resources, it is possible for the company to innovate on its products. One of the competitive advantages of the company can be seen from the company's ability to innovate. The innovations made by the company cause the products or services produced to be unique compared to the products or services produced by other competing companies. Innovations made by the company can also be 
viewed in terms of product strengthening innovations from materials that are no longer used (recycled) as well as innovations in waste management. Companies that implement Environmental Management Accounting (EMA) tend to always innovate whose products are tailored to the desires and trends of the ever-evolving market. This can happen because with the implementation of Environmental Management Accounting (EMA) the availability of raw materials will continue to be guaranteed.

Product recycling is one of the innovations made by the company, namely by creating new products made from products that are no longer used. The implementation of Environmental Management Accounting (EMA) will include recycling and processing of residual production waste. Companies that are able to produce recycled products and treat waste properly can be said to have a competitive advantage. It can be said that because not all companies have been and are able to innovate through recycling and waste treatment activities properly. Research conducted by Utomo (2019) concluded that the strategy to increase the value of the company is to make investments based on green business (environmentally friendly). Green-based investment is an asset-based investment that synchronizes economic orientation and commitment to environmental orientation. Environmentally friendly investments are believed to have a positive impact on company value. In addition, Azizah, Dzulkirom and Wi Endang (2013) concluded that a strategy based on environmentally friendly efforts is no longer a strategy category that is only used to fulfill corporate social responsibility as this is already related to the existence and position of the company's strategy. Therefore, it is certain that every company that implements Environmental Management Accounting (EMA) in any form of program will have advantages over companies that do not implement Environmental Management Accounting (EMA).

The results of the study above explain that every company that carries out activities using environmentally friendly concepts through the implementation of Environmental Management Accounting (EMA) is certain to have a higher value compared to other companies. It can be said that due to the implementation of Environmental Management Accounting (EMA), by automatically the company has made innovations to its products, production processes and waste treatment.

\section{CONCLUSION}

The implementation of Environmental Management Accounting (EMA) consists of benefits in terms of compliance with laws and regulations set by the government, benefits for achieving eco-efficiency and benefits for achieving the company's strategic position. The relationship between the implementation of management accounting (EMA) with competitive advantage can be seen from the management strategy carried out by the company which includes a low cost strategy, differentiation strategy, focus strategy and innovation strategy. Further research needs to be done with primary data research with a quantitative approach.

\section{REFERENCES}

Adediran, S. A., \& Alade, S. O. (2013). The Impact of Environmental Accounting on Corporate Performance in Nigeria. European Journal of Business \& Management, 5(23), 141-152. Diakses dari https://www.iiste.org/ Journals/index.php/ EJBM/article/view/7485/7809.

Azizah, N., A.R., M. D., \& Endang, M. G. W. (2011). Analisis Environmental Management Accounting (EMA) Sebagai Bentuk Eco-Efficiency Dalam Meningkatkan Keunggulan Kompetitif Perusahaan. 6(2), 1-10. https://media.neliti.com/media/publications/78000-ID-analisis-penerapanenvironmental-managem.pdf 
Burritt, R. L. (2012). Environmental Performance Accountability: Planet, People, Profits. Accounting, Auditing \& Accountability Journal, 25(2), 370-405. doi: https://doi.org/10.1108/09513571211198791.

Bartolomeo, M., Bennett, M., Bouma, JJ., Heydkamp, P., dan Wolters, T. (2000). Environmental Management Accounting in Europe: Current Practice and Future Potential. The Eurpoean Accounting Review, Vol 9. No.1.

Bouten, L. \& S. Hoozée. (2013). Tentang interaksi antara pelaporan lingkungan dan perubahan akuntansi manajemen. Riset Akuntansi Manajemen 24, 333-348.

Buhr, N., R. Gray \& MJ Milne. (2014). Sejarah, Alasan, Standar Sukarela dan Masa Depan Prospek Pelaporan Keberlanjutan - CSR, GRI, IIRC dan seterusnya. Di dalam: Akuntansi dan Akuntabilitas Keberlanjutan, 51-71. Bebbington, J., J. Unerman \& B. O'Dwyer. New York: Routledge. *ISBN: 978-0-415-69558-9

Carolina, V., \& Martusa, R. (2009). Akuntansi Lingkungan: Solusi untuk Problematika Penerapan Corporate Social Responsibility di Indonesia. Problematika Hukum Dalam Implementasi Bisnis Dan Investasi.

Craven (1996). Pemasaran Strategis. Jilid I. (terjemahan). Jakarta: Penerbit Erlangga.

Chenhall, R.H., (2003). Management Control Systems Design within Its Organizational Context: Findings from Contingency-Based Research and Directions for the Future. Accounting, Organizations and Soci-ety, 28.

Chang, Huei-Chun. (2007). Environmental Management Accounting Within Universities: Current State and Future Potential. RMIT University: USA.

Gibassier, D., \& Alcouffe, S. (2018). Environmental Management Accounting: The Missing Link to Sustainability? Social and Environmental Accountability Journal, 38(1), 1-18. https://doi.org/10.1080/0969160X.2018.1437057

Gunawan, Eric. (2012). Tinjauan Teoritis Biaya Lingkungan Terhadap Kualitas Produk dan Konskuensinya Terhadap Keunggulan Kompetitif Jurnal Imliah Mahasiswa Akuntansi Vol 1 No 2, Maret 2012

Hansen, D.R., dan Ma Maryanne M. Mowen. (2007). Managerial Accounting. Eight Edition. USA: Thomson Higher Education..

Hatef, J.M., Abar, M. N., \& Dadashian, F. (2016). Environmental Management Accounting Model on the Basis of Environmental Management System in Leather Industry. International Journal of Environmental Science and Development, 7(1), 52-58. https://doi.org/10.7763/ijesd.2016.v7.740

Hendaris, R.,B. (2010). Akuntansi Lingkungan: Mendorong Keunggulan Kompetitif Bagi Perusahaan. Vol 7, No. 1, Mei 2010: $70-76$

Huseno, T. (2018). The Environmental Management Accounting (EMA) Perspective Calculation of Environmental Management Environment in Riau. Jurnal Aplikasi Manajemen, 16(4), 714-721. https://doi.org/10.21776/ub.jam.2018.016.04.18

IFAC (International Federation of Accountants). 2005. International Guidance Document: Environmental Management Accounting.. 
Jasch, C., \& Stasiskiene, Z. (2005). From Environmental Management Accounting to Sustainability Management Accounting. Environmental Research, Engineering and Management, 34(4), 77-88.

Nyide, C. J. (2016). Environmental Management Accounting: A Conceptual Model for the Reporting of Environmental Costs. Corporate Ownership and Control, 14(1Continued1), 195-202. https://doi.org/10.22495/cocv14i1c1p3

Prasetya, S. G. (2020). The effect of earnings management upon the investment efficiency using the company size as the variable of moderated agent (Empirics study at the companies registered at the Indonesia stock exchange 2014-2018). $\begin{array}{llll}\text { The Accounting Journal of Binaniaga, 5(01), 61-72. } & \text {. }\end{array}$ DOI: https://doi.org/10.33062/ajb.v5i01.368

Ratno, F. P. A., \& Rosdiana, Y. (2020). Pengaruh Penerapan Akuntansi Manajemen Lingkungan terhadap Keunggulan Kompetitif Perusahaan. 104-107. http://repository.unisba.ac.id/handle/123456789/26913

N Ruslinawati, SG. Prasetya. (2021). Influence of organizational culture, leadership and decision making on employee performance at the Ministry of Defense of the Republic of Indonesia. The Management Journal of Binaniaga 6 (1), 41-54. DOI: HYPERLINK https://doi.org/10.33062/mjb.v6i1.385 "https://doi.org/10.33062/mjb.v6i1.385"

Utomo, M. N., \& Pratiwi, S. R. (2016). Analisis Penerapan Green Business terhadap Kinerja UKM Tarakan. Quality, 6(2), 143-150.

Undang-undang Nomor 32 Tahun 2009 Tentang Perlindungan dan Pengelolaan Lingkungan Hidup (PPLH) 
The Accounting Journal of BINANIAGA Vol. 06, No. 02, December 2021

p-ISSN: 2527-4309, e-ISSN: 2580-1481

$5^{\text {th }}$ Accreditation Rating: January 14, 2019 - January 13, 2024

This page intentionally be emptied

Syarief Gerald Prasetya. Implementation Of Environmnetal Management Accounting (Ema)

To Achieve Competitive Advantage

Page: 104 